\title{
Influence of Forest Management on Acorn Production in the Southeastern Missouri Ozarks: Early Results of a Long-Term Ecosystem Experiment
}

\author{
Matthew G. Olson, Alexander J. Wolf, Randy G. Jensen* \\ Forest Systems Field Station, Resource Science Division, Missouri Department of Conservation, West Plains, \\ Missouri, USA \\ Email: matthew.olson@mdc.mo.gov, alex.wolf@mdc.mo.gov
}

Received 19 June 2015; accepted 26 July 2015; published 30 July 2015

Copyright (C) 2015 by authors and Scientific Research Publishing Inc. This work is licensed under the Creative Commons Attribution International License (CC BY). http://creativecommons.org/licenses/by/4.0/

(c) (i)

Open Access

\begin{abstract}
Since acorn production is a foundational process of ecosystems dominated by oaks, understanding the impact of forest management practices on acorn production is critical to the sustainable management of oak forests. This investigation addressed the impact of even-aged management (EAM), uneven-aged management (UAM), and no-harvest management (NHM) on the production of mature, sound acorns over an 18-year period (1993-2010) of a long-term, landscape-scale forest management experiment in the Missouri Ozarks. Forest management impacts were investigated at two operational scales: the multi-stand compartment and the stand. We hypothesized that acorn production at both scales would be lower under active management (EAM and UAM) than NHM on these oak-dominated landscapes. Acorn production (acorns/ha/year) of red oaks (mainly black oak (Quercus velutina) and scarlet oak ( $Q$. coccinea)) at the compartment level was lower under active management than NHM during the post-treatment period (1997-2010), but not for white oaks (mainly white oak $(Q . a l b a)$ and post oak $(Q$. stellata)), which was largely a result of greater abundance and preferential harvesting of mature red oaks. At the stand scale, acorn production following either intermediate thinning or single-tree selection was comparable to yields observed in untreated stands suggesting that partial overstory removal can be implemented for harvesting timber and other silvicultural objectives without sacrificing acorn production. In many oak-dominated forests, active management will be necessary to mitigate future losses of acorn production driven by oak decline, succession, and climate change, including approaches for sustaining oak recruitment and acorn production.
\end{abstract}

"Deceased.

How to cite this paper: Olson, M. G., Wolf, A. J., \& Jensen, R. G. (2015). Influence of Forest Management on Acorn Production in the Southeastern Missouri Ozarks: Early Results of a Long-Term Ecosystem Experiment. Open Journal of Forestry, 5, 568-583. http://dx.doi.org/10.4236/ojf.2015.55051 


\section{Keywords}

\section{Oak, Quercus, Hard Mast, Silviculture, Ecosystem Management}

\section{Introduction}

Acorn production is a foundational process of oak (Quercus) forest ecosystems. Aside from its obvious importance in the sexual reproduction of oaks, acorns are also a primary food source of many vertebrate and invertebrate species. As a food source, acorns are high in energy content and digestibility but low in protein and key nutrients (Goodrum et al., 1971; Short \& Epps, 1976; Kirkpatrick \& Pekins, 2002). According to one estimate, nearly 100 bird and mammal species consume acorns in North America (Martin et al., 1961). Acorn production can influence ecosystems in complex ways through trophic interactions (Ostfeld, 2002) and is considered a keystone resource (Wolff, 1996). The inter-annual variability in acorn production influences the dynamics of wildlife populations, including numerous ecologically important bird and mammal species (McShea \& Healy, 2002). In turn, the impact of acorn consumers on acorns and how this impact changes with consumer population dynamics can affect oak regeneration dynamics, oak recruitment, and the future production of acorns (Healy, 1997; Feldhamer, 2002; Ostfeld, 2002). Acorn production has even been linked to gypsy moth outbreaks (Elkinton et al., 1996) and Lyme's disease infection (Jones et al., 1998).

Acorn production exhibits large temporal variation and many factors have been linked to this variability. Differences in acorn production occur not only among oak species but also among individuals within a species (Greenberg, 2000; Koenig \& Knops, 2002). Generally speaking, large, dominant trees produce more acorns than their smaller, suppressed counterparts (Goodrum et al., 1971; Greenberg, 2000), which, aside from differences in vigor, is also related to higher density of acorn-bearing branches and greater exposure of dominant tree crowns to direct sunlight (Greenberg \& Parresol, 2002; Johnson et al., 2009; Rose et al., 2012). Several studies have found that populations of oaks are often composed of inherently good and poor acorn producers (Greenberg, 2000; Koenig \& Knops, 2002). Insects and external factors, such as weather, can also affect acorn production (Fearer et al., 2008; Johnson et al., 2009), especially weather events that impact flowering and pollination (Cecich \& Sullivan, 1999; Johnson et al., 2009). In forests composed of multiple oak species, acorn production by some species compensates for low production by others during most years (Burns et al., 1954; Christisen \& Korschgen, 1955; Goodrum et al., 1971; Sork et al., 1993; Koenig \& Knops, 2002). It has been hypothesized that inter-annual fluctuation in acorn yield is an evolved strategy for overwhelming acorn predator populations, enhancing pollination efficiency, or a more complicated compromise among multiple selection pressures rather than simply a response to fluctuating resource availability (Koenig \& Knops, 2002).

The high value of oaks as both desirable timber species and sources of food for wildlife makes oak-dominated forests ideally suited for sustainable management that balances ecological and commodity objectives. Maintaining or increasing the abundance of oak species on many sites will require some form of active forest management to support oak recruitment and eventual advancement into the overstory (Dey et al., 2010). Active management may also help to mitigate negative effects of oak decline, including preventing diminished acorn yield (Greenberg et al., 2014). However, there is still uncertainty about what impact active management of oak forests will have on acorn production. Understanding the effect of management practices on acorn yield and other ecosystem processes is critical to the sustainable management of oak forests.

There is considerable interest in boosting acorn production to benefit wildlife and oak regeneration through silviculture. Past research addressing the effects of partial overstory removal treatments on acorn production has emphasized impacts on individual-tree production, while comparatively fewer studies have addressed impacts at the stand level. Several studies have observed higher individual-tree acorn yields in thinned stands compared to unthinned stands (Harlow \& Eikum, 1963; Paugh, 1970; Healy, 1999). Individual trees retained in stands treated with different regeneration methods produced more acorns than in untreated areas and acorn production at the individual-tree level increased with basal area reduction (Perry \& Thill, 2003). Perry \& Thill (2003) also found that stand-level yields were higher under group selection than other treatments, including untreated stands.

Less is known about the impact of forest management practices on acorn production at operational scales of forest management ranging from the stand up to the compartment (a multi-stand unit of forest management). 
This study investigated the influence of three forest management systems commonly applied to state lands in the Missouri Ozarks during the first 14-year period following initiation of management systems and considered the impacts of management at two operational scales: the multi-stand compartment and the stand. At the compartment scale, we hypothesized that acorn production would be lower under active management than no-harvest management as a result of reduced densities of adult oaks due to harvesting. We also hypothesized that compartment-level acorn yield would be lowest under even-aged management, intermediate under uneven-aged management, and highest where no harvesting has occurred. At the stand scale, we hypothesized that previously untreated stands treated for the first time with a single partial overstory removal would have a lower acorn yield than untreated stands and that acorn production would increase in partially cut stands during the post-harvest period as a result of enhanced individual-tree growth and vigor stimulated by overstory density reduction. We also expected acorn production to vary among different landscape positions as a result of inherent variation in the density of adult oaks on the landscape both before and after harvest.

\section{Methods}

\subsection{Study Sites}

This investigation used data collected over 18 years (1993-2010) on sites of the Missouri Ozark Forest Ecosystem Project (MOFEP). MOFEP is a long-term, multi-disciplinary program evaluating the effect of alternative forest management systems on Ozark forests of southeastern Missouri, USA. Three management systems were initiated as treatments of the MOFEP experiment: even-aged management (EAM), uneven-aged management (UAM), and no-harvest management (NHM). The active management systems, even-aged and uneven-aged, were designed to represent approaches taken by the Missouri Department of Conservation (MDC) for managing public land in the southeast Ozarks. For nearly a quarter century, the MOFEP experiment has been a platform for multi-agency, collaborative research on managed forests (Knapp et al., 2014).

The MOFEP experiment employs a randomized complete block design (RCBD) of three blocks with the three management systems randomly assigned to three sites per block and a total of nine sites. MOFEP sites range in size from 314 to 516 ha. Each MOFEP site is an administrative compartment composed of 44 - 82 stands ranging from 0.2 - 62 ha. MOFEP sites are located on two MDC-administered Conservation Areas in southeastern Missouri (Figure 1). All MOFEP sites fall within the Current River Ecological Subsection of the Ozark Highlands

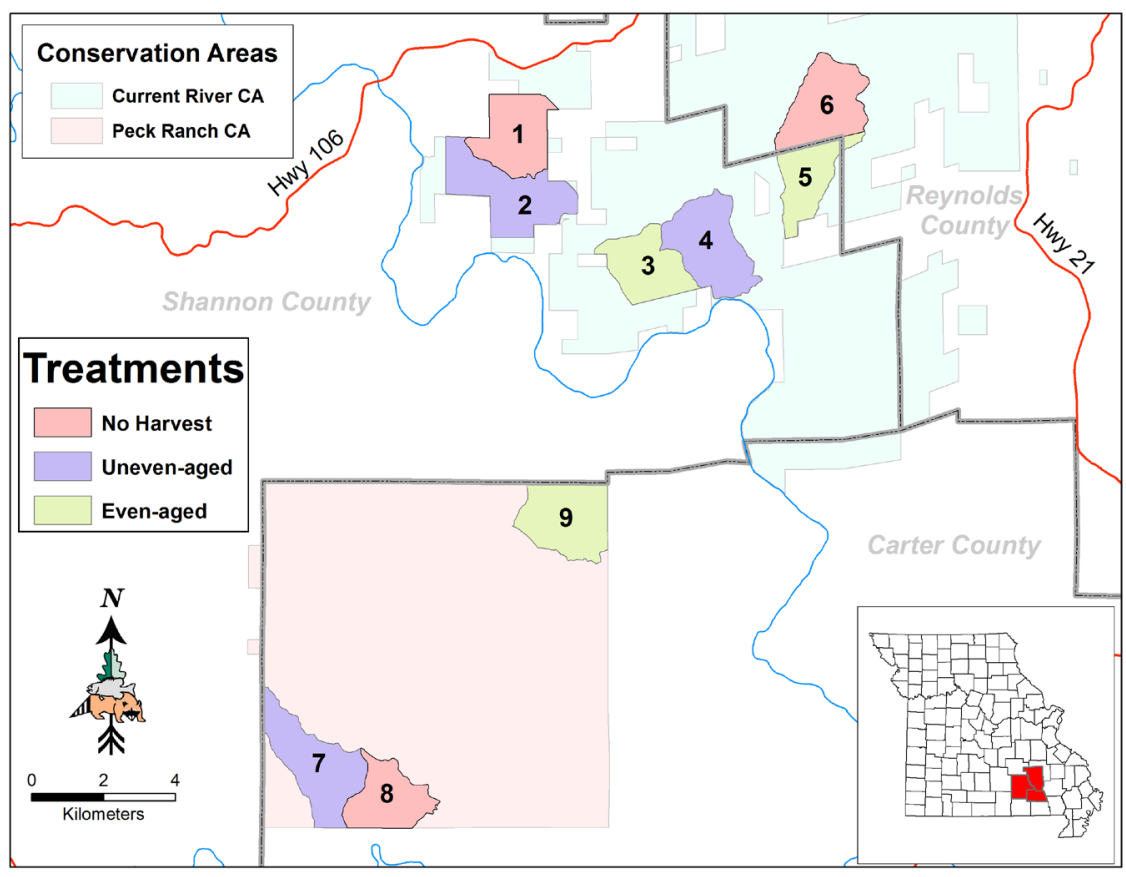

Figure 1. Nine sites of the MOFEP experiment in Missouri, USA. Inset image (lower right) is the state of Missouri. 
Section (Nigh \& Schroeder, 2002). MOFEP sites are underlain mainly by Ordovician dolomites and sandstones (Meinert et al., 1997). Soils are highly weathered Ultisols and Alfisols derived mainly within loess, hillslope sediments, residuum, and gravelly alluvial parent material (Meinert et al., 1997).

Treatments under EAM and UAM systems of the MOFEP experiment were implemented from May 1996 to May 1997. The management cycle of both systems starts with a pre-treatment inventory of a compartment that is accomplished by inventorying each stand individually. This information is used to prescribe appropriate silviculture treatments to each stand that also considers management impacts at the compartment level. Under MOFEP's EAM system, approximately $12 \%$ of the compartment is regenerated by clearcutting of mature stands every 15 years. Thinning is also applied as an intermediate treatment under EAM. Under MOFEP's UAM system, stands are treated with single-tree selection and tending of size-classes according to the BDq method on the same 15-year cycle as the EAM system. Group openings may also be created along with single-tree selection to regenerate tree species of lower shade tolerance (e.g., scarlet oak (Quercus coccinea) and shortleaf pine (Pinus echinata)). Approximately $10 \%$ of each site was reserved as old growth under both systems prior to the first treatment entry. To date, there have been two treatment entries on MOFEP sites (1996-1997 and 2011-2012). See Brookshire et al. (1997) and Knapp et al. (2014) for more on treatment implementation of the MOFEP experiment.

\subsection{MOFEP Hard Mast Project}

The MOFEP hard mast project was initiated to evaluate the effects of MDC forest management systems on the production of acorns. The hard mast project uses a split-plot RCBD with the three management systems as whole-plot treatment and landscape position as the subplot factor. Since MOFEP sites are large enough to capture relatively high variability in soils and topography, each site was initially stratified into landscape positions, defined by slope position and aspect, in order to help account for landscape variation analytically. Hard mast sampling plots were randomly assigned to four landscape strata (subplots): south and west facing side slopes (SW), ridge tops (R), north and east facing side slopes (NE), and upland waterways and drainages (WD). SW, R, and NE strata alone account for nearly 90\% of MOFEP sites (Vangilder, 1997). The number of sampling plots within a stratum is proportional to its extent within a site with a total of 14 - 16 per site and a total of 130 sampling plots experiment wide. See Table 1 for details on the impact of the 1996-1997 harvest on hard mast sampling plots.

The MOFEP hard mast project captures acorn yield at the stand level rather than production at the scale of individual trees. Each hard mast sampling plot consists of an array of 20 inverted cone traps on a $5 \times 4$ grid with traps spaced at $8.7 \mathrm{~m} \times 7.7 \mathrm{~m}$ apart and nested within a larger overstory sampling plot. The area of each trap opening is $0.42 \mathrm{~m}^{2}$ for a total of $8.40 \mathrm{~m}^{2}$ per array. The species, dbh, and condition of overstory trees ( $\mathrm{dbh} \geq 11.4$ $\mathrm{cm}$ ) above each trap array are recorded on a $2267 \mathrm{~m}^{2}$ area. The sampling plot boundary for capturing overstory

Table 1. Count and proportion of hard mast sampling plots within forest management systems partitioned by stand management practices of the 1996-1997 harvest.

\begin{tabular}{|c|c|c|c|}
\hline Management system & Stand prescription & Count of plots & Percent of total \\
\hline \multirow[t]{5}{*}{ EAM } & Clearcutting (CC) & 12 & 27.3 \\
\hline & Thinning (TH) & 11 & 25.0 \\
\hline & $\mathrm{CC}-\mathrm{TH}^{\mathrm{a}}$ & 2 & 4.5 \\
\hline & Leave & 19 & 43.2 \\
\hline & Total & 44 & \\
\hline \multirow[t]{4}{*}{ UAM } & Single-tree selection (SS) & 18 & 41.9 \\
\hline & SS with group openings & 11 & 25.6 \\
\hline & Leave & 14 & 32.5 \\
\hline & Total & 43 & \\
\hline \multirow[t]{2}{*}{ NHM } & No harvest; total & 43 & \\
\hline & Grand total & 130 & \\
\hline
\end{tabular}

${ }^{\mathrm{a}} \mathrm{CC}-\mathrm{TH}$ refers to stands where part of the stand was clearcut and the rest was thinned. 
trees extends approximately $10 \mathrm{~m}$ beyond the outer-most traps to include trees whose crowns overtop the traps but are rooted outside of the array.

During hard mast collection years, traps are visited weekly from the time acorns begin to drop (as early as late-July) to when acorn fall ceases (as late as mid-January). All acorns are collected during each weekly visit and stored in paper bags for processing once collection that year is finished. For each hard mast sampling plot, acorns are initially sorted into species and then into four maturity classes based on acorn morphology. Next, the mature acorns are partitioned into groups based on whether or not they were eaten by wildlife (mammal or bird species) and counted. Mature acorns without wildlife damage are then cut open to determine if cotyledons are fully formed and to inspect for evidence of insect and other forms of internal damage. Finally, the numbers of mature acorns with and without internal damage are recorded separately.

Acorn collection started in 1993 and was carried out for three consecutive years (1993-1995) prior to the 1996-1997 treatment entry. Hard mast collection resumed in 1997 and continued annually until 2010, the last collection year before the second treatment entry of the MOFEP experiment. A change in protocol in 2003-2004 rendered the data from these collection years unusable for this investigation. Therefore, the post-treatment period of this investigation consists of two, 6-year periods from 1997-2002 and 2005-2010. Over the 18-year period covered in this study, the overstory trees above traps arrays were inventoried in 1995, 1998, 2005, and 2010.

\subsection{Analytical Approach}

Analysis of variance (ANOVA) for a split-plot RCBD was used to test for effects of forest management (whole plot) and landscape position (subplot) on mean annual production of mature, sound acorn (i.e., acorns/ha/year) and was performed separately for red oak species (mainly black oak (Quercus velutina) and scarlet oak), white oak species (mainly white oak (Q. alba) and post oak (Q. stellata)), and all oak species combined. ANOVA models of mean annual acorn yield were generated for the pre-treatment period (1993-1995) and MOFEP's first post-treatment period (1997-2002 and 2005-2010 combined). Analysis was performed at two management scales. For analysis at the site level (i.e., multi-stand compartment), treatments were the three forest management systems (EAM, UAM, and NHM). For stand-level analysis, four stand management practices were selected to serve as treatments: clearcutting with reserves (CC), single-tree selection (SS), thinning (TH; EAM only), and no harvest (NH; NHM only). Estimates of both site and stand level yield were expressed on a per hectare basis. However, since these management systems impact a portion of a compartment in each entry and this study covers only the period following the first treatment, site level estimates were calculated from both treated and untreated stands within each compartment, which captured the response of acorn yield at the larger, site level. For assessing impacts of stand management practices, acorn yields for each practice were calculated from only those stands receiving that treatment. Additionally, repeated measures ANOVA models were used to test for effects of partial cutting (thinning and single-tree selection) and no-harvest management on mean annual acorn production over the two, 6-year periods after treatment: 1997-2002 (early post-treatment) and 2005-2010 (late post-treatment). Model residuals were checked for normality and equal variance. When distributional assumptions were violated, a square-root transformation was applied. Statistical significance was assessed at $\alpha=$ 0.05. Fisher's least significant difference was used for comparing levels of significant fixed effects from ANOVA models. All statistical procedures were performed in SAS 9.2 (SAS Institute Inc., 2008).

\section{Results}

\subsection{Management System and Landscape Position}

The production of mature, sound acorns exhibited substantial inter-annual variation yet temporal trends were fairly consistent across treatments. During the pre-treatment period (1993-1995), mean annual acorn yield of red oak species varied from 1100 acorns/ha in 1993 among sites designated for EAM to 178,000 acorns/ha in 1994 among sites designated for UAM (Figure 2(a)). Production by red oaks in 1994 among UAM sites was the highest recorded for this species group over the study period. Pre-treatment acorn production by white oak species varied from 700 acorns/ha in 1994 (UAM) to 101,000 acorns/ha in 1995 (EAM; Figure 2(b)). Over the first post-treatment period of MOFEP (1997-2010), acorn production by red oak species ranged from a high of 133,000 acorns/ha in 1997 under NHM to zero acorns collected in 2008 across the entire network of hard mast 


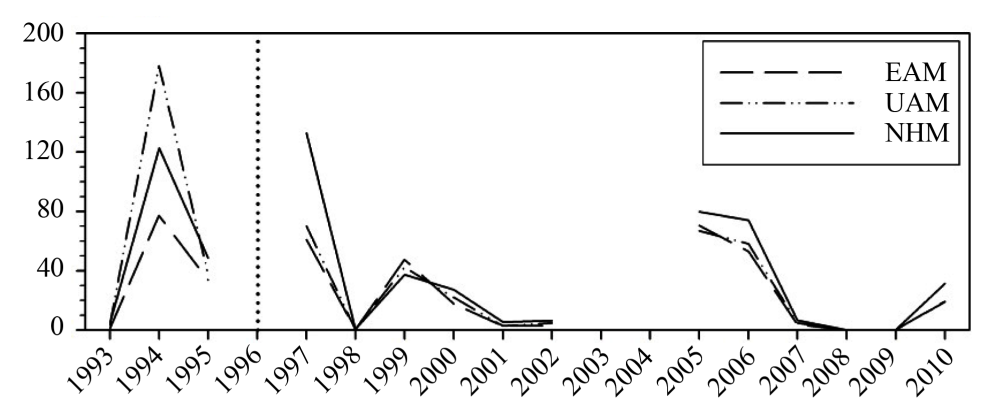

(a)

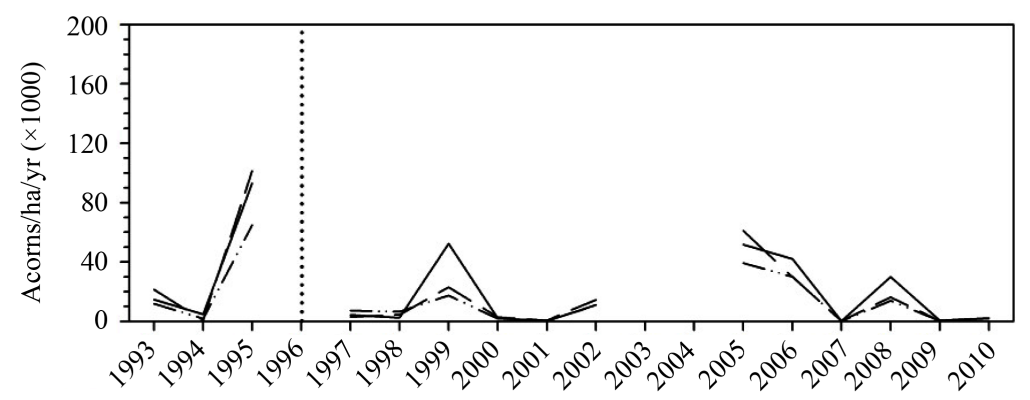

(b)

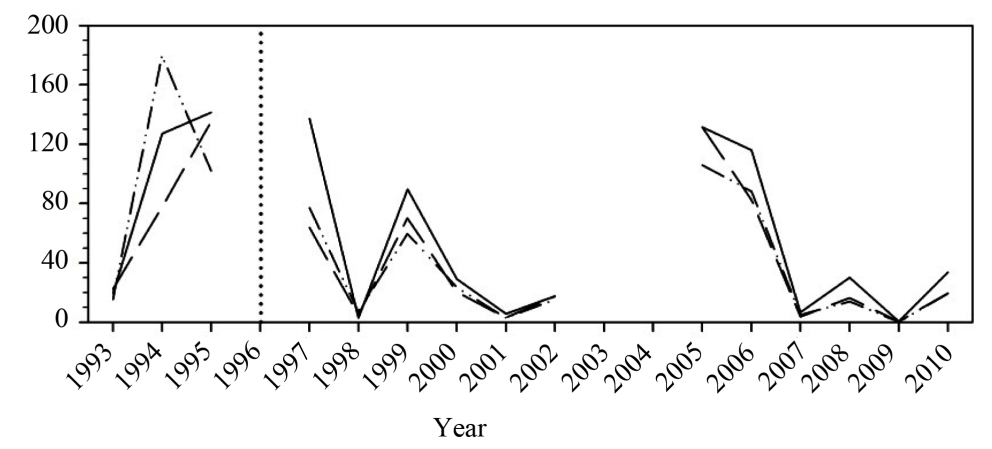

(c)

Figure 2. Mean annual production of mature sound, acorns (acorns/ha) by (a) red oaks, (b) white oaks, and (c) all oaks within three forest management systems over an 18-year period of the MOFEP experiment.

plots. White oak acorn production during the post-treatment period varied from a low of zero acorns collected in 2007 under UAM to a high of 61,000 acorns/ha under EAM in 2005. There were several years with no red oak or white oak acorns collected and very small crops of all oak species (Figure 2(c)). However, there was no year that acorns were not collected.

Forest management system was not a significant source of variation in ANOVA models of pre-treatment production of mature, sound acorns (Table 2), which suggests that yields were comparable among the randomly assigned treatments prior to initiation of management (Figure 3). Landscape position was a significant factor in models of pre-treatment acorn production for red oak species and all oak species, but not white oak species. Mean separation indicated that acorn production of red oak species and all oak species was lowest on WD landforms and higher on R than SW positions (Figure 4). This spatial pattern in acorn yield matched the pre-treatment distribution of basal area of adult red oak species ( $\mathrm{dbh} \geq 25.4 \mathrm{~cm}$ ) across landscape positions (Figure 5(a)).

ANOVA models of post-treatment acorn production detected significant effects of forest management system and landscape position for red oak and all oak species, but not for white oak species (Table 2). Mean separation found that post-treatment red oak acorn production was lower under EAM than NHM, yet no differences were detected between UAM and the other systems (Figure 3). For all oak species, post-treatment production was significantly lower under both EAM and UAM than NHM. Contrasts found significantly lower post-treatment 
Table 2. ANOVA results for fixed effects from models of pre-treatment (1993-1995) and post-treatment (1997-2010) mean annual production of mature, sound acorns (acorns/ha/yr) for red oaks, white oaks, and all oaks under three forest management systems of the MOFEP experiment. A contrast comparing EAM and UAM against NHM was performed for posttreatment production. Source of variation (SV) and contrast abbreviations are: M, management system; E, ecological land type; MxE, interaction between management system and ecological landtype; E + Uv. NH, contrast for EAM and UAM versus NHM. Significant $p$-values are in bold $(p<0.05)$.

\begin{tabular}{|c|c|c|c|c|c|c|c|c|c|c|}
\hline \multirow{2}{*}{$\begin{array}{c}\text { SV \& } \\
\text { Contrast }\end{array}$} & \multirow{2}{*}{ ndf } & \multicolumn{3}{|c|}{ Red oak species } & \multicolumn{3}{|c|}{ White oak species } & \multicolumn{3}{|c|}{ All oak species } \\
\hline & & ddf & $\mathrm{F}$ & $p>\mathrm{F}$ & ddf & F & $p>\mathrm{F}$ & ddf & $\mathrm{F}$ & $p>\mathrm{F}$ \\
\hline \multicolumn{11}{|c|}{ Pre-treatment } \\
\hline M & 2 & 5.6 & 1.05 & 0.408 & 22 & 2.84 & 0.080 & 5.6 & 0.57 & 0.594 \\
\hline E & 3 & 15.9 & 8.03 & 0.002 & 22 & 0.66 & 0.585 & 15.9 & 12.78 & $<0.001$ \\
\hline MxE & 6 & 15.9 & 0.73 & 0.634 & 22 & 0.45 & 0.835 & 15.9 & 1.09 & 0.409 \\
\hline \multicolumn{11}{|c|}{ Post-treatment } \\
\hline M & 2 & 20.0 & 3.92 & 0.037 & 20.2 & 1.84 & 0.184 & 20.0 & 7.76 & 0.003 \\
\hline $\mathrm{E}$ & 3 & 20.1 & 4.39 & 0.016 & 20.3 & 0.11 & 0.954 & 20.0 & 4.52 & 0.014 \\
\hline MxE & 6 & 20.0 & 0.31 & 0.927 & 20.2 & 0.34 & 0.907 & 20.0 & 0.40 & 0.872 \\
\hline $\mathrm{E}+\mathrm{Uv} \cdot \mathrm{NH}$ & 1 & 20.0 & 7.10 & 0.015 & 20.1 & 3.13 & 0.092 & 19.9 & 15.21 & $<0.001$ \\
\hline
\end{tabular}

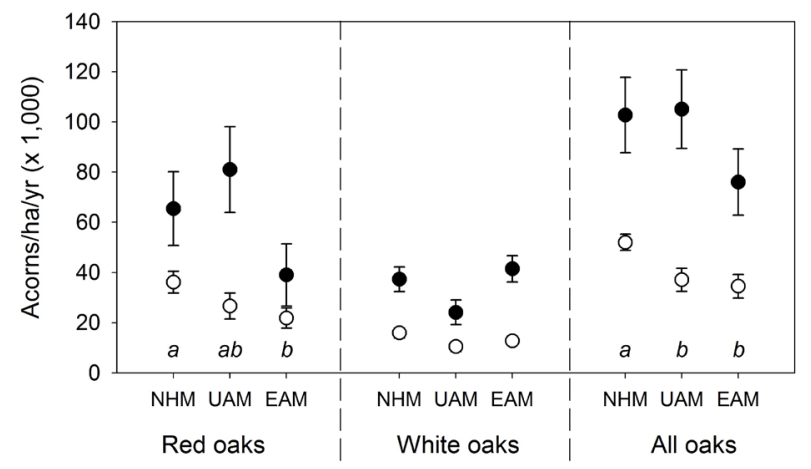

Figure 3. Mean annual production of mature, sound acorns ( \pm 1 standard error) by red oaks, white oaks, and all oaks within three forest management systems, averaged over ecological land types, captured before (1993-1995; black circles) and after (1997-2010; white circles) initiating forest management systems of the MOFEP experiment. Means followed by the same italicized letter within a species group are not statistically different based on Fisher's protected least significant difference $(\alpha=0.05)$. The bottom row of letters applies to post-treatment means only.

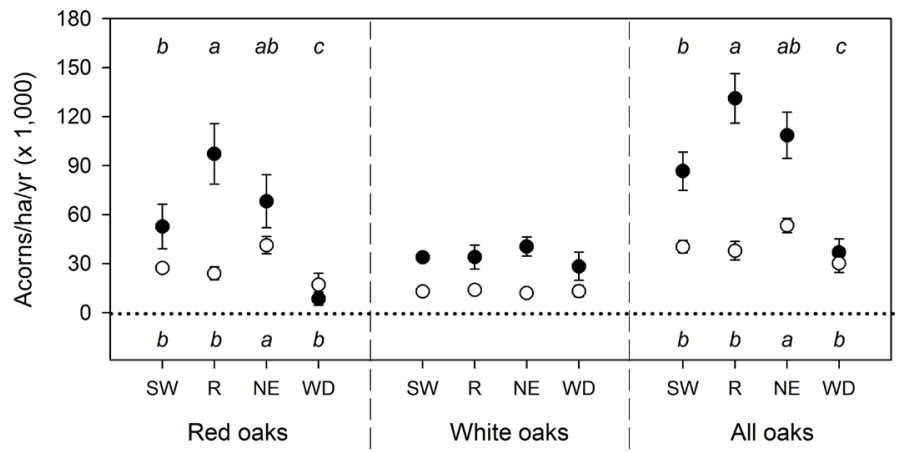

Figure 4. Mean annual production of mature, sound acorns ( \pm 1 standard error) by red oaks, white oaks, and all oaks on four ecological land types, averaged over forest management systems, captured before (1993-1995; black circles) and after (1997-2010; white circles) initiating forest management systems of the MOFEP experiment. Means followed by the same italicized letter within a species group are not statistically different based on Fisher's protected least significant difference $(\alpha=0.05)$. The top and bottom row of letters applies to pre-treatment and post-treatment means, respectively. 

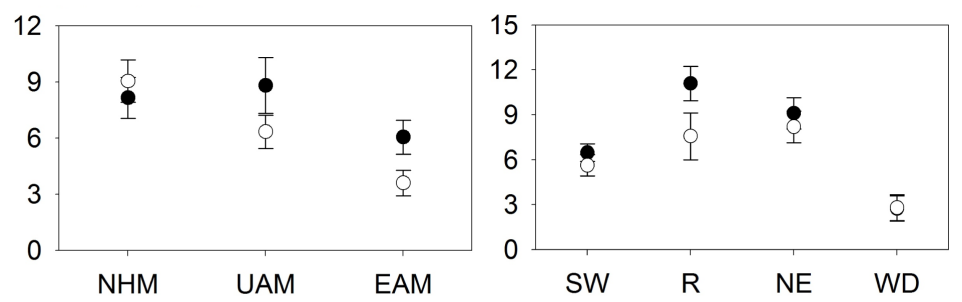

(a)
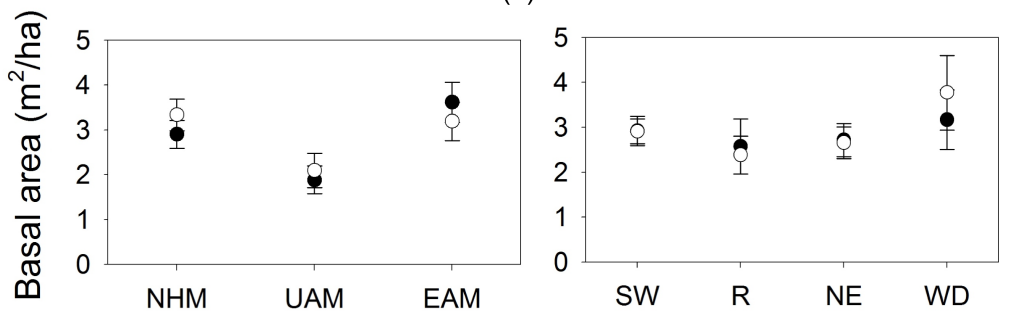

(b)
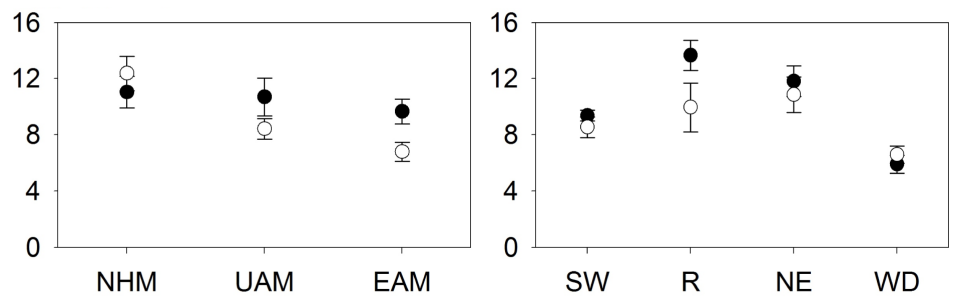

(c)

Figure 5. Mean basal area $\left(\mathrm{m}^{2} / \mathrm{ha}\right)$ of trees $\geq 25.4 \mathrm{~cm} \mathrm{dbh}$ ( \pm 1 standard error) of (a) red oaks, (b) white oaks, and (c) all oaks above hard mast collection traps under three forest management systems (left column), averaged over ecological land types, and on four ecological land types (right column), averaged over management systems, captured before (1995; black circles) and after (1998; white circles) initiating forest management systems of the MOFEP experiment.

acorn yield under active management (combination of EAM and UAM) than NHM (Table 2). Declines in production coincided with decreases in the basal area of red oak species in actively managed sites shortly after treatment (Figure 5(a)). Post-treatment acorn production by red oak species and all oak species was highest on northeast side slopes and comparable among the three other landscape positions (Figure 4). Declines in acorn production on SW, R, and NE positions between pre- and post-treatment periods coincided with reductions in basal area of similar magnitude.

\subsection{Stand Management Practice}

Stand management practice was a significant source of variation in the ANOVA model of pre-treatment acorn production for red oak species only (Table 3), suggesting inherent differences in acorn yield between stands that were assigned different silvicultural treatments prior to implementation. Specifically, mean separation detected lower production of acorns in stands treated with CC than those treated with SS to treatment (Figure 6). Landscape position was not a significant source of variation.

Stand management practice was a significant factor in ANOVA models of post-treatment acorn production for red oak species, white oak species, and all oak species, but not landscape position (Table 3). For all three oak species groups, post-treatment acorn yield was lowest in CC stands, while no differences were detected among TH, SS, and NH stands (Figure 6).

\subsection{Partial Overstory Removal}

According to repeated measures ANOVA, time and interaction of time and stand management practice were 
Table 3. ANOVA results for fixed effects from models of pre-treatment (1993-1995) and post-treatment (1997-2010) mean annual production of mature, sound acorns (acorns/ha/yr) for red oaks, white oaks, and all oaks following four stand management practices of the MOFEP experiment. Source of variation (SV) abbreviations are: E, ecological land type; S, stand management prescription, ExS, interaction between ecological landtype and stand management prescription. Significant $p$-values are in bold $(p<0.05)$.

\begin{tabular}{|c|c|c|c|c|c|c|c|c|c|c|}
\hline \multirow{2}{*}{ SV } & \multirow{2}{*}{ ndf } & \multicolumn{3}{|c|}{ Red oak species } & \multicolumn{3}{|c|}{ White oak species } & \multicolumn{3}{|c|}{ All oak species } \\
\hline & & ddf & F & $p>\mathrm{F}$ & ddf & $\mathrm{F}$ & $p>\mathrm{F}$ & ddf & $\mathrm{F}$ & $p>\mathrm{F}$ \\
\hline \multicolumn{11}{|c|}{ Pre-treatment } \\
\hline M & 2 & 18.3 & 2.26 & 0.132 & 20 & 0.03 & 0.967 & 18.2 & 2.28 & 0.130 \\
\hline $\mathrm{E}$ & 3 & 18.7 & 3.83 & 0.027 & 20 & 0.46 & 0.716 & 18.5 & 2.39 & 0.102 \\
\hline $\mathrm{MxE}$ & 6 & 18.3 & 0.74 & 0.622 & 20 & 0.78 & 0.598 & 18.2 & 0.39 & 0.876 \\
\hline \multicolumn{11}{|c|}{ Post-treatment } \\
\hline M & 2 & 4.7 & 2.11 & 0.223 & 3.9 & 0.68 & 0.560 & 4.3 & 0.94 & 0.410 \\
\hline $\mathrm{E}$ & 3 & 15.2 & 67.71 & $<0.001$ & 15 & 12.72 & $<0.001$ & 15.4 & 57.01 & $<0.001$ \\
\hline MxE & 6 & 15.5 & 1.23 & 0.345 & 15 & 0.15 & 0.986 & 15.6 & 0.72 & 0.602 \\
\hline
\end{tabular}

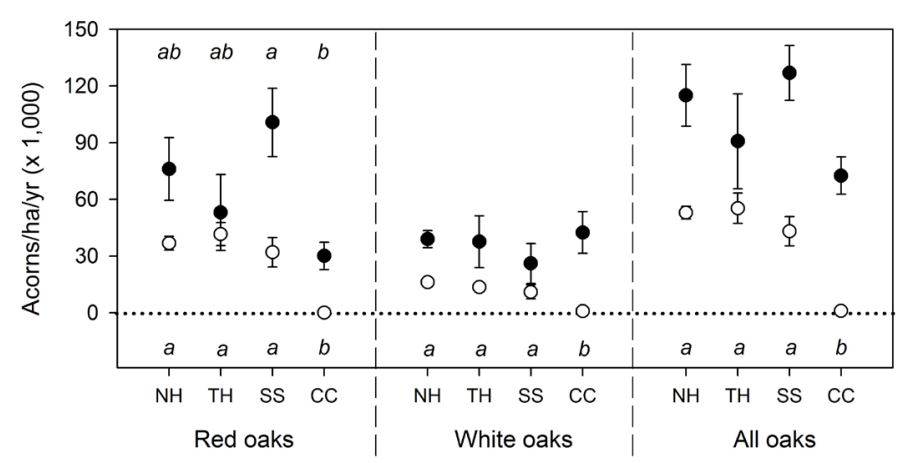

Figure 6. Mean annual production of mature, sound acorns ( \pm 1 standard error) by red oaks, white oaks, and all oaks within four stand management practices, averaged over ecological land types, captured before (1993-1995; black circles) and after (1997-2010; white circles) treatment of the MOFEP experiment. Means followed by the same italicized letter within a species group are not statistically different based on Fisher's protected least significant difference $(\alpha=0.05)$. The top and bottom row of letters applies to pre-treatment (1993-1995) and post-treatment (1997-2010) means, respectively.

significant components in models of post-treatment acorn production for white oak species and all oak species (Table 4). For white oak species, mean separation of significant interactions revealed higher acorn production during the late post-treatment period in TH and NH stands (Figure 7). All oak species also had higher acorn production during the late post-treatment period in TH stands.

For red oak species (Figure 8(a)) within hard mast plots, SS produced an immediate reduction mainly in basal area and had less of an impact on quadratic mean diameter, whereas TH reduced both basal area and quadratic mean diameter. There was no immediate reduction in either basal area or quadratic mean diameter of white oak $(\mathrm{dbh} \geq 25.4 \mathrm{~cm})$ in either SS or TH stands (Figure $8(b))$. Collectively, these patterns suggest that both partial cutting treatments targeted the removal of mainly red oak species, that this removal was more equable across the range of tree diameters in SS stands, and that the TH targeted larger red oaks. By 2010, the basal area of red oak species rebounded in TH stands, slightly exceeding pre-treatment basal area, while red oak basal area in SS stands rebounded marginally. Basal area of white oak species also showed a larger increase in TH stands compared to SS stands from 1998-2010. However, quadratic mean diameter of both red oak species and white oak species exhibited larger increases after SS than TH during the post-treatment period.

\section{Discussion}

\subsection{Acorn Production at the Compartment Level}

Our results support the hypothesis that acorn production at the compartment level was lower under active 
Table 4. Repeated measures ANOVA results for fixed effects from models of early (1997-2002) and late (2005-2010) post-treatment mean annual production of mature, sound acorns (acorns/ha/yr) for red oaks, white oaks, and all oaks following three stand management practices on three ecological landtypes of the MOFEP experiment. Source of variation (SV) abbreviations are: E, ecological land type; S, stand management prescription; T, time period. Significant $p$-values are in bold $(p<0.05)$.

\begin{tabular}{|c|c|c|c|c|c|c|c|c|c|c|}
\hline \multirow{2}{*}{ SV } & \multirow{2}{*}{ ndf } & \multicolumn{3}{|c|}{ Red oak species } & \multicolumn{3}{|c|}{ White oak species } & \multicolumn{3}{|c|}{ All oak species } \\
\hline & & ddf & $\mathrm{F}$ & $p>\mathrm{F}$ & ddf & $\mathrm{F}$ & $p>\mathrm{F}$ & ddf & $\mathrm{F}$ & $p>\mathrm{F}$ \\
\hline$E^{\mathrm{a}}$ & 2 & 13 & 3.36 & 0.055 & 15 & 0.54 & 0.592 & 13.1 & 1.39 & 0.285 \\
\hline $\mathrm{S}$ & 2 & 13.2 & 1.10 & 0.362 & 15 & 0.76 & 0.487 & 13.4 & 1.00 & 0.394 \\
\hline ExS & 4 & 13 & 1.12 & 0.388 & 15 & 0.04 & 0.996 & 13.1 & 0.55 & 0.703 \\
\hline $\mathrm{T}$ & 1 & 15 & 2.84 & 0.112 & 15 & 62.46 & $<0.001$ & 15 & 12.69 & 0.003 \\
\hline TxE & 2 & 15 & 0.57 & 0.576 & 15 & 0.23 & 0.797 & 15 & 0.38 & 0.691 \\
\hline $\mathrm{TxS}$ & 2 & 15 & 0.59 & 0.567 & 15 & 3.36 & 0.032 & 15 & 3.13 & 0.048 \\
\hline TxExS & 4 & 15 & 0.48 & 0.748 & 15 & 1.59 & 0.228 & 15 & 0.30 & 0.871 \\
\hline
\end{tabular}

${ }^{a}$ ANOVA did not include data from the ecological landtype upland waterways and drainages due to low replication.

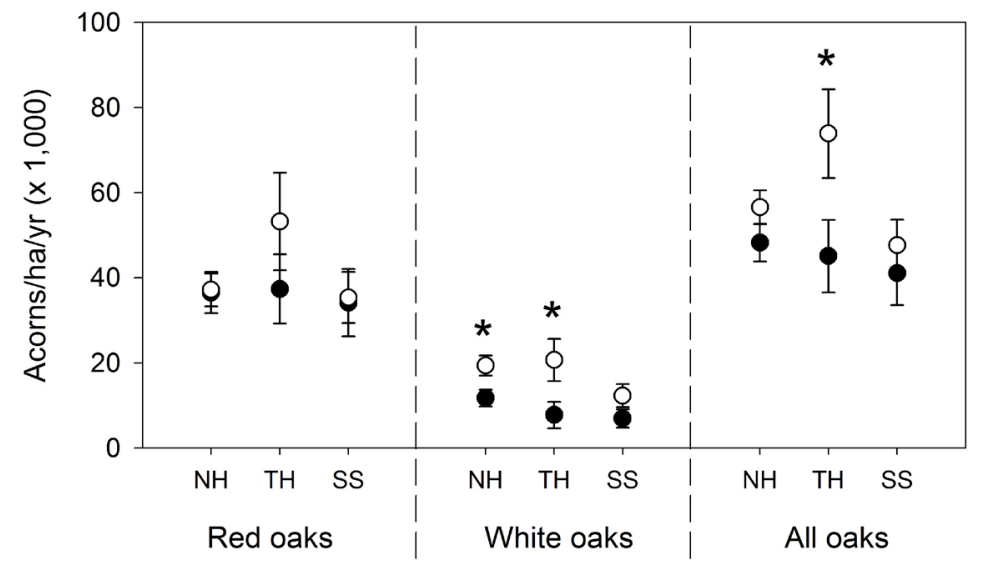

Figure 7. Mean annual production of mature, sound acorns ( \pm 1 standard error) during early (1997-2002; black circles) and late (2005-2010; white circles) post-treatment periods by red oak spp., white oak spp., and all oak spp. within three stand management prescriptions, averaged over ecological land types, of the MOFEP experiment. Asterisk indicates a significant difference in acorn production between early and late periods within a stand management prescription based on Fisher's protected least significant difference $(\alpha=0.05)$.

management than no-harvest management as a result of overstory removal in these oak-dominated landscapes. This result was found for red oak species and all oaks species combined, but not white oak species. The decrease in total oak production was likely more of a response to greater pre-harvest basal area and preferential harvesting of red oaks during the first MOFEP treatment entry (Kabrick et al., 2002). There are multiple lines of evidence in support of a forest management effect on acorn yield of red oaks. Significantly lower post-treatment production on actively managed sites coupled with the absence of a detectable effect of the designated treatments on acorn yield prior to implementation (i.e., pseudo-treatment effect) suggest that active management lowered acorn production during the first post-treatment period. Decreases in the basal area of mature red oak species in the vicinity of hard mast plots in sites under active management, especially on ridges and side slopes, supports the role of timber harvesting in diminishing acorn yield. We also hypothesized that compartment-level acorn yield would be lowest under EAM, intermediate under UAM, and highest under NHM. This hypothesis was partially supported by results for red oaks, which had a lower post-treatment acorn yield under EAM than NHM, while acorn production under UAM was comparable to the other systems.

However, effects of forest management on site-level acorn yield need to be interpreted cautiously. The 1996-1997 treatment entry affected a disproportionately large number of hard mast plots relative to the area that 


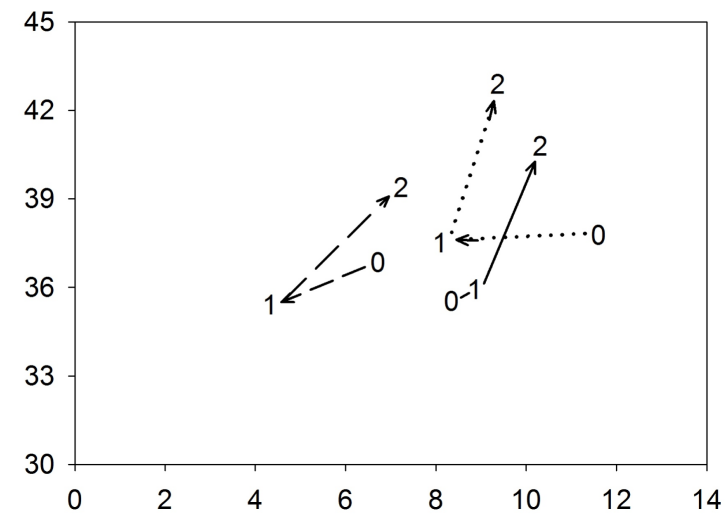

(a)

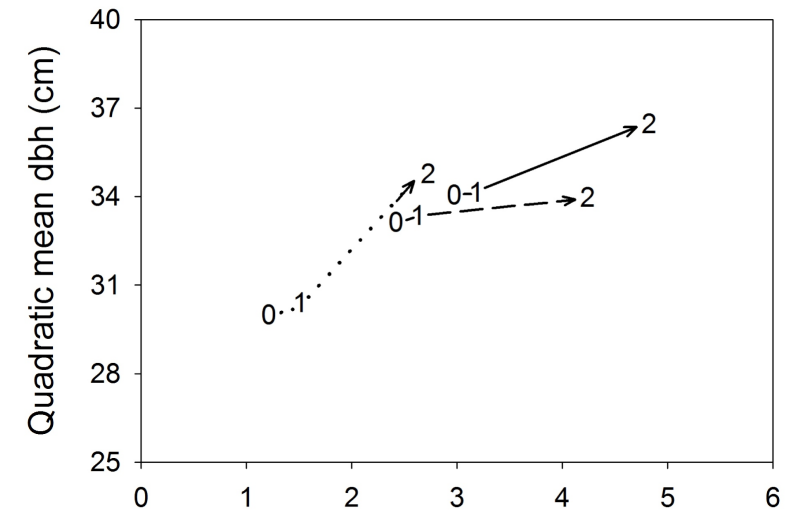

(b)
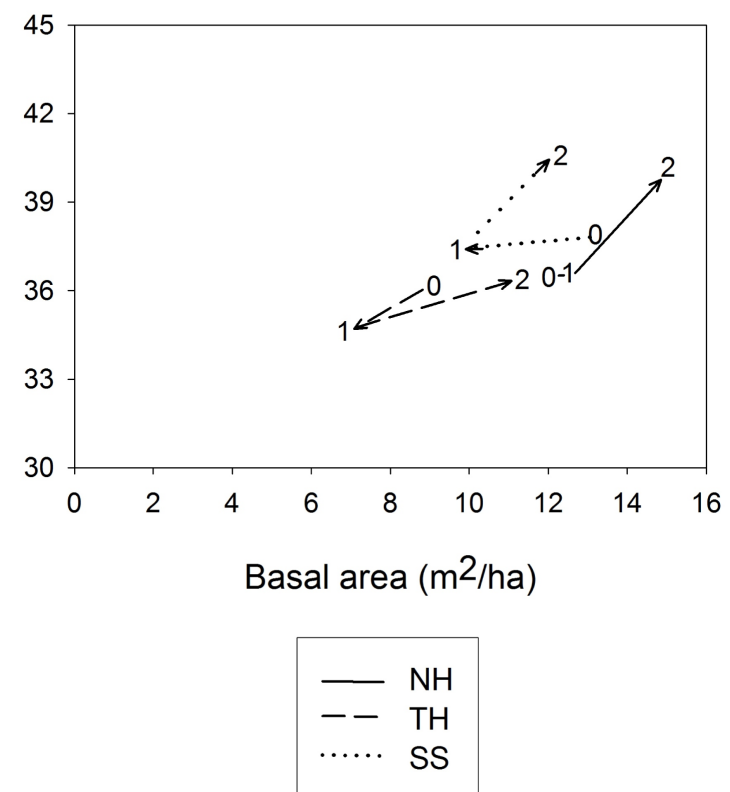

(c)

Figure 8. Mean basal area and quadratic mean dbh of (a) red oaks, (b) white oaks, and (c) all oaks $\geq 25.4 \mathrm{~cm}$ dbh recorded in 1995 (0), 1998 (1), and 2010 (2) above hard mast collection traps within three silvicultural prescriptions, averaged over ecological land types, of the MOFEP experiment. 
was actually treated at the compartment level. For example, clearcutting and thinning on average impacted 11\% and 15\% of the EAM sites in 1996-1997, respectively (Kabrick et al., 2002), whereas 57\% of the hard mast plots in EAM sites occurred within treated stands, including 32\% falling entirely or partially within stands treated with clearcutting. Under UAM, an average of 57\% of the area was treated with selection methods in 1996-1997 (Kabrick et al., 2002), which impacted $67 \%$ of hard mast plots. Therefore, it is likely that the effect of management system on acorn production was partly an artifact of the first treatment entry having a disproportionately greater impact on the hard mast study than the compartments as a whole. This disproportionate impact may disappear as additional stands across each compartment are treated in subsequent harvests.

We also expected acorn production to vary among different landscape positions as a result of inherent variation in the density of adult oaks $(\mathrm{dbh} \geq 25.4 \mathrm{~cm})$ on the landscape both before and after harvest. Prior to the 1996-1997 treatment, red oak acorn yield was highest on ridgetops and northeast side slopes, which is also where the density of mature red oaks was greatest. Acorn production by red oaks during the post-treatment period was still higher on northeast side slopes, but, with the exception of upland waterways and drainages, yields were substantially lower than pre-treatment, especially on ridgetops. Once again, decreases in acorn production coincided with immediate post-treatment reductions in basal area of mature red oaks on hard mast plots, which were greatest on ridgetops and side slopes. This suggests that harvesting was concentrated on these more extensive and widespread landscape positions. Silvicultural prescriptions were implemented in stands in greatest need of treatment during the 1996-1997 entry on MOFEP sites (Brookshire et al., 1997). These were mainly stands of declining black oak and scarlet oak. Because of their higher risk of mortality and lower probability of surviving until the next treatment entry, senescent red oaks exhibiting crown dieback (i.e., oak decline) are often targeted for removal.

Compared to the red oaks, the distribution of adult white oak species was remarkably uniform across landscape positions both before and after treatment, which helps to explain similar levels of production across these oak-dominated landscapes over the study period. The factors explaining this difference in spatial distribution between oak subgenera are at least partly linked to disturbance history at these sites and autecological differences between red oak and white oak groups. Landscape-scale variation in the abundance of oak species is partly a legacy of exploitative timber harvesting around the start of the last century. The greater relative abundance of red oak species on higher landscape positions is likely related to greater competitive ability of red oak species on xeric sites after a major disturbance. Using the MOFEP experiment, Kabrick et al. (2008b) found that red oak species regenerated at highest densities in clearcuts, especially on drier landforms where non-oak competitor densities were lower. The uniform distribution of white oaks could be related to a number of factors, such as slower height growth compared to red oaks in open conditions (Vickers et al., 2014) and higher shade tolerance of white oaks. A higher shade tolerance would enable this species group to survive suppression, continue to recruit new stems, and, perhaps, maintain a more uniform abundance of mature trees on these oak-dominated landscapes.

\subsection{Acorn Production at the Stand Level}

At the stand scale, we hypothesized that previously untreated stands treated for the first time with a single partial overstory removal, in this case intermediate thinning or single-tree selection, would have a lower acorn yield than untreated stands. This expectation was based on past research indicating that partial cutting boosts individual-tree acorn production yet often diminishes acorn yield at the stand level. Our analysis found that post-treatment acorn production in stands treated with a one-time intermediate thinning or single-tree selection treatment was comparable to yields observed in untreated stands, which does not support our hypothesis. The reason for this could be that increased individual-tree acorn production from the residual stand compensated for lost production from harvested trees or simply that the overstory removal resulting from both thinning and single-tree selection was not heavy enough to reduce acorn yield at the stand level. Greenberg \& Parresol (2002) suggested that inconsistent results on the influence of partial overstory removal on stand-level acorn yield could be attributable to unknowingly removing a disproportionate number of either good or poor acorn producers. On state land in the Missouri Ozarks, silvicultural thinning and single-tree selection often target senescent oaks for removal. Since senescent oaks are poor acorn producers (Goodrum et al., 1971), another possible explanation is that these treatments disproportionately removed poor acorn producers that contributed less to acorn yield at the stand scale than residual oaks. Unfortunately, the stand-level acorn collection approach of the MOFEP hard mast 
project does not allow us to differentiate between good and poor producers so we are unable to determine if indiscriminate removal of either has influenced our results.

Our study revealed that a one-time thinning or single-tree selection treatment did not diminish stand-level acorn production over the first 14 years of this long-term experiment. This interpretation has important implications for the management of oak-dominated forests. Thinning is applied to mature oak stands for a variety of objectives, such as timber production, enhancing forest health, adjusting species composition, improving wildlife habitat, and restoring natural communities with an oak component, such as oak woodlands (Johnson et al., 2009). Although it is not as widely used as thinning to manage oak forests of the Central Hardwood Region, single-tree selection is applied more extensively for sustaining oak recruitment in the Missouri Ozarks (Johnson et al., 2009). This finding suggests that partial overstory removal can be implemented for harvesting timber and a variety of silvicultural objectives without sacrificing acorn production.

We also hypothesized that acorn production would increase in partially cut stands during the post-harvest period as a result of enhanced individual-tree growth and vigor stimulated by overstory density reduction (i.e., thinning effect). Our results partially supported this hypothesis for white oak species and all oak species combined, but not for red oak species. Increased acorn production was observed in thinned stands but not those treated with single-tree selection. However, acorn yield of white oaks also increased in untreated stands suggesting that other factors, such as weather or inherent variation among study sites (e.g., differences in the abundance or condition of adult white oak), could have also affected acorn yield during the post-treatment period.

\subsection{Acorn Production over Time}

The timeframe of this study covers the first post-treatment period after initiating management systems that are designed to transform a landscape dominated by a single age class to one composed of multiple age classes (i.e., compartment transformation). At the compartment scale, the ecological impacts of these management systems are cumulative with successive entries until the process of transitioning the entire site to either an area-regulated compartment composed of even-aged stands (EAM) or to a compartment composed of structurally regulated uneven-aged stands (UAM) is complete. Under EAM, the length of this transformation is equal to the rotation length of individual stands. Under UAM, this transition will require multiple of treatments, which may take less time than EAM to transform a site. Regardless how long this transformation takes, it is important to consider the impacts of management systems on acorn production reported in this study as preliminary findings of a longterm, landscape-scale experiment.

Although this study only covers the early stages of compartment transformation, our results suggest that active management will play an important role in acorn production at the compartment-level over time. Acorn production on sites under an EAM system that uses clearcutting as the primary regeneration method will likely continue to decline with successive treatment entries until older clearcut stands begin to yield enough acorns to slow this decline. Under UAM, compartment-level acorn yield may also decline as a result of shifting standlevel stocking from mainly mature trees to a mixture of age classes with younger, immature cohorts making up a larger component. Once transformation is complete, periodic acorn production, or yield averaged over segments of consecutive years, of compartments under active management may reach a plateau with fluctuations that are less than the total yield (i.e., quasi-equilibrium) and these production patterns may differ between EAM and UAM systems. Of course, this assumes that oak is maintained. In forest landscapes dominated by droughty, low-quality sites, like the Missouri Ozarks, this assumption is more tenable than in more mesic forests with a component of oak (Johnson et al., 2009). If adequate oak regeneration is developed under either of these management systems, then tending treatments that favor oak and boost individual-tree vigor may be necessary to maintain acorn production and might even increase it; especially if good acorn producers are identified and preferentially retained (Healy et al., 1999; Greenberg \& Parresol, 2002). Active management at least affords the opportunity to manage acorn production at the compartment scale through silvicultural interventions designed to maintain a vigorous oak component at the stand level.

In the absence of active management (i.e., NHM sites), changes in acorn production over time on landscapes dominated by mature oak forest will depend on many factors. Red oak decline, in particular, has the potential to reduce acorn production on both managed and unmanaged landscapes. Greenberg et al. (2014) simulated acorn production in a southern Appalachian landscape under a no-management scenario both with and without oak decline over a 50-year period. Over the simulation, acorn yield (acorns/ha) increased by nearly 60\% without oak 
decline, but, with oak decline, diminished by nearly 20\%. Dominant red oak species of MOFEP sites are black and scarlet oak, both of which are considered shorter-lived species and acutely vulnerable to decline (Shifley et al., 2006; Kabrick et al., 2008a; Voelker et al., 2008). Therefore, it is reasonable to postulate that acorn production will decline on these and similar sites in the absence of management. Sustainable forest management of oak ecosystems for meeting multiple resource objectives, including acorn production, will become increasingly important for mitigating negative impacts of oak decline and adapting to climate change.

\section{Conclusions}

For many oak-dominated landscapes, active management will be necessary to mitigate future losses of acorn production driven by oak decline, succession, and climate change, including approaches for sustaining oak recruitment and acorn production in the long term. It is important to keep in mind that the management implications that can be drawn from this study apply mainly to oak forests growing on dry sites. Therefore, the silviculture methods covered herein may need to be modified to address regional management issues in more mesic oak-dominated landscapes (e.g., the oak sapling bottleneck).

An important finding of this study is that partial overstory removal treatments that preferentially remove senescent red oaks can simultaneously harvest timber for forest products, improve individual-tree vigor and stand health, and sustain the recruitment of oak species without sacrificing stand-level acorn production. Although clearcutting will cause an immediate loss of acorns, this regeneration method, when applied judiciously as part of a silvicultural system, can be used to initiate new oak stands that will eventually contribute to acorn production. Heavier overstory removal treatments, such as clearcutting, low-density shelterwood methods, or group selection, may also be necessary to regenerate shade-intolerant red oak species. Despite large inter-annual variation in the total number of acorns produced, there was not a complete crop failure in any year during this study on these oak-diverse landscapes. Although this finding supports the long-held notion that a diverse mix of oak species reduces the probability of a total crop failure (Christisen \& Korschgen, 1955; Goodrum et al., 1971; Sork et al., 1993; Koenig \& Knops, 2002), there were several years that the total crop was very small. Regardless of this finding, management practices that maintain a mix of white oak and red oak species at the stand or compartment scale should help to buffer these systems from a total crop failure and benefit oak regeneration and mast-easting wildlife by providing an annual supply of acorns.

\section{Acknowledgements}

We thank all who have contributed to the MOFEP hard mast project since its inception. For this investigation, we thank Sherry Gao for statistical advice. We also thank the Missouri Department of Conservation for its commitment to supporting this project as part of the long-term, multi-disciplinary MOFEP experiment.

\section{References}

Brookshire, B. L., Jensen, R. G., \& Dey, D. C. (1997). The Missouri Ozark Forest Ecosystem Project: Past, Present, and Future. In B. L. Brookshire, \& S. R. Shifley (Eds.), Proceedings of the Missouri Ozark Forest Ecosystem Project Symposium: An Experimental Approach to Landscape Analysis (pp. 1-25), General Technical Report NC-193. St. Paul, MN: USDA Forest Service, North Central Research Station.

Burns, P. Y., Christisen, D. M., \& Nichols, J. M. (1954). Acorn Production in the Missouri Ozarks, Agriculture Experiment Station Bulletin 611. Columbia, MO: University of Missouri.

Cecich, R. A., \& Sullivan, N. H. (1999). Influence of Weather at Time of Pollination on Acorn Production of Quercusalba and Quercus velutina. Canadian Journal of Forest Research, 29, 1817-1823. http://dx.doi.org/10.1139/cjfr-29-12-1817

Christisen, D. M., \& Korschgen, L. J. (1955). Acorn Yields and Wildlife Usage in Missouri. In Transactions of the Twentieth North American Wildlife Conference (pp. 337-357). Washington DC: Wildlife Management Institute.

Dey, D. C., Royo, A. A., Brose, P. H., Hutchinson, T. E., Spetich, M. A., \& Stoleson, S. H. (2010). An Ecologically Based Approach to Oak Silviculture: A Synthesis of 50 Years of Oak Ecosystem Research in North America. Revista Columbia Forestal, 13, 201-222.

Elkinton, J. S., Healy, W. M., Buonaccorsi, J. P., Boettner, G. H., Hazzard, A. M., Smith, H. R., \& Loebhold, A. M. (1996). Interactions among Gypsy Moths, White-Footed Mice, and Acorns. Ecology, 77, 2332-2334. http://dx.doi.org/10.2307/2265735

Fearer, T. M., Norman, G. W., Pack, J. C., Bittner, S., \& Healy, W. M. (2008). Influence of Physiographic and Climatic 
Factors on Spatial Patterns of Acorn Production in Maryland and Virginia, USA. Journal of Biogeography, 35, $2012-2025$. http://dx.doi.org/10.1111/j.1365-2699.2008.01960.x

Feldhamer, G. A. (2002). Acorns and White-Tailed Deer: Interrelationships in Forest Ecosystems. In W. J. McShea, \& W. M. Healy (Eds.), Oak Forest Ecosystems: Ecology and Management for Wildlife (pp. 215-223). Baltimore, MD: Johns Hopkins University Press.

Goodrum, P. D., Reid, V. H., \& Boyd, C. E. (1971). Acorn Yields, Characteristics, and Management Criteria of Oaks for Wildlife. Journal of Wildlife Management, 35, 520-532. http://dx.doi.org/10.2307/3799707

Greenberg, C. H. (2000). Individual Variation in Acorn Production by Five Species of Southern Appalachian Oaks. Forest Ecology and Management, 132, 199-210. http://dx.doi.org/10.1016/S0378-1127(99)00226-1

Greenberg, C. H., \& Parresol, B. R. (2002). Chapter 10: Dynamics of Acorn Production by Five Southern Appalachian Oaks. In W. J. McShea, \& W. M. Healy (Eds.), Oak Forest Ecosystems: Ecology and Management for Wildlife (pp. 149-172). Baltimore, MD: Johns Hopkins University Press.

Greenberg, C. H., Keyser, C. E., Rathbun, L. C., Rose, A. K., Fearer, T. M., \& McNab, W. H. (2014). Forecasting Long-Term Acorn Production with and without Oak Decline Using Forest Inventory Data. Forest Science, 60, $222-230$. http://dx.doi.org/10.5849/forsci.12-106

Harlow, R. F., \& Eikum, R. L. (1963). The Effects of Stand Density on the Acorn Production of Turkey Oaks. Proceedings of the Annual Conference of Southeastern Game and Fish Commissions, 17, 126-133.

Healy, W. M. (1997). Thinning New England Oak Stands to Enhance Acorn Production. Northern Journal of Applied Forestry, 14, 152-156.

Healy, W. M., Lewis, A. M., \& Boose, E. F. (1999). Variation in Red Oak Acorn Production. Forest Ecology and Management, 116, 1-11. http://dx.doi.org/10.1016/S0378-1127(98)00460-5

Johnson, P. S., Shifley, S. R., \& Rogers, R. (2009). The Ecology and Silviculture of Oaks (2nd ed.). New York: CABI Publishing. http://dx.doi.org/10.1079/9781845934743.0000

Jones, C. G., Osfeld, R. S., Richard, M. P., Schauber, E. M., \& Wolff, J. O. (1998). Chain Reactions Linking Acorns to Gypsy Moth Outbreaks and Lyme Disease Risk. Science, 279, 1023-1026. http://dx.doi.org/10.1126/science.279.5353.1023

Kabrick, J. M., Dey, D. C., Jensen, R. G., \& Wallendorf, M. (2008a). The Role of Environmental Factors in Oak Decline and Mortality in the Ozark Highlands. Forest Ecology and Management, 255, 1409-1417. http://dx.doi.org/10.1016/j.foreco.2007.10.054

Kabrick, J. M., Jensen, R. G., Shifley, S. R., \& Larsen, D. R. (2002). Woody Vegetation Following Even-Aged, Uneven-Aged, and No-Harvest Treatments on the Missouri Ozark Forest Ecosystem Project Sites. In S. R. Shifley, \& J. M. Kabrick (Eds.), Proceedings of the Second Missouri Ozark Forest Ecosystem Project Symposium: Post-Treatment Results of the Landscape Experiment (pp. 84-101). General Technical Report NC-227. St. Paul, MN: USDA Forest Service, North Central Research Station.

Kabrick, J. M., Zenner, E. K., Dey, D. C., Gwaze, D., \& Jensen, R. G. (2008b). Using Ecological Land Types to Examine Landscape-Scale Oak Regeneration Dynamics. Forest Ecology and Management, 255, 3051-3062. http://dx.doi.org/10.1016/j.foreco.2007.09.068

Kirkpatrick, R. L., \& Pekins, P. J. (2002). Chapter 11: Nutritional Value of Acorns for Wildlife. In W. J. McShea, \& W. M. Healy (Eds.), Oak Forest Ecosystems: Ecology and Management for Wildlife (pp. 173-181). Baltimore, MD: Johns Hopkins University Press.

Knapp, B. O., Olson, M. G., Larsen, D. R., Kabrick, J. M., \& Jensen, R. G. (2014). Missouri Ozark Forest Ecosystem Project: A Long-Term, Landscape-Scale, Collaborative Forest Management Research Project. Journal of Forestry, 112, 513-524. http://dx.doi.org/10.5849/jof.13-102

Koenig, W. B., \& Knops, J. M. H. (2002). Chapter 9: The Behavioral Ecology of Masting in Oaks. In W. J. McShea, \& W. M. Healy (Eds.), Oak Forest Ecosystems: Ecology and Management for Wildlife (pp. 129-148). Baltimore, MD: Johns Hopkins University Press.

Martin, A. C., Zim, H. S., \& Nelson, A. L. (1961). American Wildlife and Plants: A Guide to Wildlife Food Habits. New York: Dover Publishers.

McShea, W. J., \& Healy, W. M. (Eds.). (2002). Oak Forest Ecosystems: Ecology and Management for Wildlife. Baltimore, MD: Johns Hopkins University Press.

Meinert, D., Nigh, T. A., \& Kabrick, J. M. (1997). Landforms, Geology, and Soils of the MOFEP Study Area. In B. L. Brookshire, \& S. R. Shifley (Eds.), Proceedings of the Missouri Ozark Forest Ecosystem Project Symposium: An Experimental Approach to Landscape Analysis (pp. 56-68). General Technical Report NC-193. St. Paul, MN: USDA Forest Service, North Central Research Station. 
Nigh, T. A., \& Schroeder, W. A. (2002). Atlas of Missouri Ecoregions. Jefferson City, MO: Missouri Department of Conservation.

Ostfeld, R. S. (2002). Chapter 13: Ecological Webs Involving Acorns and Mice: Basic Research and Its Management Implications. In W. J. McShea, \& W. M. Healy (Eds.), Oak Forest Ecosystems: Ecology and Management for Wildlife (pp. 196-214). Baltimore, MD: Johns Hopkins University Press.

Paugh, J. H. (1970). Effects of Thinning on Acorn Production on the West Virginia University Forest. M.S. Thesis, Morgantown, WV: West Virginia University.

Perry, R. W., \& Thill, R. E. (2003). Initial Effects of Reproduction Cutting Treatments on Residual Hard Mast Production in the Ouachita Mountains. Southern Journal of Applied Forestry, 27, 253-258.

Rose, A. A., Greenberg, C. H., \& Fearer, T. M. (2012). Acorn Production Prediction Models for Five Common Oak Species of the Eastern United States. The Journal of Wildlife Management, 76, 750-758. http://dx.doi.org/10.1002/jwmg.291

SAS Institute Inc. (2008). SAS 9.2: Help and Documentation. Cary, NC: SAS Institute Inc.

Shifley, S. R., Fan, Z., Kabrick, J. M., \& Jensen, R. G. (2006). Oak Mortality Risk Factors and Mortality Estimation. Forest Ecology and Management, 229, 16-26. http://dx.doi.org/10.1016/j.foreco.2006.03.033

Short, H. L., \& Epps Jr., E. A. (1976). Nutrient Quality and Digestibility of Seeds and Fruit from Southern Forests. Journal of Wildlife Management, 40, 283-289. http://dx.doi.org/10.2307/3800427

Sork, V. L., Bramble, J., \& Sexton, O. (1993). Ecology of Mast-Fruiting in Three Species of North American Deciduous Oaks. Ecology, 74, 528-541. http://dx.doi.org/10.2307/1939313

Vangilder, L. D. (1997). Acorn Production on the Missouri Ozark Forest Ecosystem Project Study Sites: Pre-Treatment Data. In B. L. Brookshire, \& S. R. Shifley (Eds.), Proceedings of the Missouri Ozark Forest Ecosystem Project Symposium: An Experimental Approach to Landscape Analysis (pp. 198-209). General Technical Report NC-193. St. Paul, MN: USDA Forest Service, North Central Research Station.

Vickers, L. A., Larsen, D. R., Knapp, B. O., Kabrick, J. M., \& Dey, D. C. (2014). The Impact of Overstory Density on Sapling Height Growth in the Missouri Ozarks: Implications for Interspecific Differentiation during Canopy Recruitment. Canadian Journal of Forest Research, 44, 1320-1330. http://dx.doi.org/10.1139/cjfr-2014-0237

Voelker, S. L., Muzika, R. M., \& Guyette, R. P. (2008). Individual Tree and Stand Level Influences on the Growth, Vigor, and Decline of Red Oaks in the Ozarks. Forest Science, 54, 8-20.

Wolff, J. O. (1996). Population Fluctuations of Mast-Eating Rodents are Correlated with Production of Acorns. Journal of Mammalogy, 77, 850-856. http://dx.doi.org/10.2307/1382690 